\title{
Credence Goods and Market Power: An Econometric Study on the Brazilian Pharmaceutical Industry
}

Eduardo P. S. Fiuza

Marcos de B. Lisboa
From Instituto de Pesquisa Econômica, Diretoria de Estudos Macroeconômicos (DIMAC/ IPEA) and Fundação Getúlio Vargas, Escola de Pós-Graduação em Economia (EPGE/FGV)

From EPGE/FGV

\section{RESUMO}

No presente artigo procuramos, tendo em mente as imperfeições de mercado apontadas pela literatura e pela experiência internacional, e com base em dados originais da indústria farmacêutica, relacionar empiricamente o preço de medicamentos no Brasil com algumas variáveis explicativas. Encontramos que, consoante com estimações anteriores da experiência norte-americana, os medicamentos líderes no Brasil, antes da lei que instituiu o medicamento genérico, acomodavam o avanço de produtos similares (do mesmo princípio ativo, porém sem o teste de bioequivalência) e se recolhiam a segmentos inelásticos do mercado, elevando seus preços. Os similares, ao contrário, ao perderem mercado, reduziam seus preços em relação ao líder, de modo que uma redução no índice de concentração do mercado total de um princípio ativo tem efeitos ambíguos sobre seus preços, dependendo se a causa é uma queda da participação do líder ou um rearranjo dentre os seguidores.

\section{PALAVRAS-CHAVE}

medicamentos genéricos, indústria farmacêutica, bens credenciais

\section{ABSTRACT}

Bearing in mind the market failures pointed out by the economic literature and following the international empirical evidence, and based on original micro data of the Brazilian pharmaceutical industry in the late 1990s, this article attempts to relate empirically drug prices in Brazil to some explaining variables. We find that, similarly to previous U.S. estimations, leading branded drugs accommodated share growth of the followers, turning towards a more inelastic market segment and raising their prices. On followers, in turn, a fall of the concentration index in a market had ambiguous effects: if due to reduced leader power, followers raised their relative prices; if due to a tougher competition within the fringe, their relative prices tended to go down.

KEY WORDS generic drugs, pharmaceutical industry, credence goods

JEL Classification

L65, C23, D82, II8, LI5, L43 


\section{INTRODUCTION}

Expenditures on pharmaceutical drugs have grown at quite high rates in the developed countries in the last decades. Amounts grew 3.5 percent a year in real terms in the OECD countries in the 1980s and 4.6 percent between 1990 and 1996. (RÊGO, 2000). Pressures for public health expenditure control intensified in Europe and in the USA from 1970 on, when the governments realized the need to place an effective control on the rising demand for public health services. In 1997, according to OECD, about 80 percent of total health expenditures in Western European countries came from public sources, including drug expenditures. The latter, in turn, represent in average 15 percent of total health expenditures. As a consequence, the adoption of public policies aiming to reduce drug prices became one of the most important issues in the health policy debate.

In Brazil, expenditures on drugs are not reimbursed neither by public nor by private sources (with a few exceptions, such as the Aids program and some drugs for continuous use). Because of their high share in the households' consumption basket, especially in the poorest strata, combined with price raises traditionally above inflation - whenever the Government did not run any price control - , the pharmaceutical industry has always been targeted by society. In the present article, we try to relate empirically drug prices to some explaining variables, based on original micro data of the pharmaceutical industry, and bearing in mind the market failures pointed out by the literature and following the international evidence. We hope thus to shed light on the current debate with some econometric foundations.

In the next section, we discuss particular features of the pharmaceutical industry's supply structure, and the effects of informational asymmetries on the demand structure due to the nature of the good. We also point out the main regulatory approaches adopted by developed countries. In the second section, we describe the industry and the consumption behavior in Brazil, as well as the evolution of Brazilian government policy applied to the industry. The third section brings a brief review of recent empirical studies on the effects of generic drugs in other markets. The fourth section 
introduces our model for the industry behavior in the second half of the 1990s, describes the data utilized and reports the main results obtained with the model. The last section sums up the conclusions.

\section{INFORMATIONAL ASYMMETRIES IN THE MARKET FOR PHARMACEUTICAL DRUGS AND IMPLICATIONS FOR COMPETITION POLICIES:}

\section{I The Pharmaceutical Industry}

The modern pharmaceutical industry is characterized by very high Research and Development (R\&D) investments and by a consequently high innovation pace, and dates back to the mid-1930s, when the first important group of antiinfective drugs was introduced, with research spreading out to other therapeutic areas after World War II. (VISCUSI, VERNON \& HARRINGTON, 1995, p. 847). ${ }^{1}$ As a whole, the industry is currently not so concentrated: the 20 world greatest companies accounted for just $\mathbf{5 2 . 6}$ percent of global sales in 1996, and the leader reached only 4.4 percent. In Brazil the concentration ratio is greater, but not so much: the top 20 firms in the industry owned 63 percent of the total market in 1998, and the leader Novartis reigned over 6.5 percent of the market only. The best selling drug Cataflam (also from Novartis) responded for only 1.5 percent of the total market. Nonetheless, this seeming market pulverization hides extremely high concentration ratios in the relevant markets, defined either by the therapeutic classes or by the pathologies themselves (see Table 1.1 with Herfindahl-Hirschman concentration indexes for selected markets, defined by the Active Principle).

1 According to the PhRMA report (2000), this industry recorded in 1999 the highest share of $\mathrm{R} \& \mathrm{D}$ on sales among all industries in the U.S. (12 percent if we take the whole industry, or as high as 20.8 percent if we restrict ourselves to the research-based pharmaceutical companies - that is, the ones based on prescription drug sales and R\&D). 
TABLE 1.1

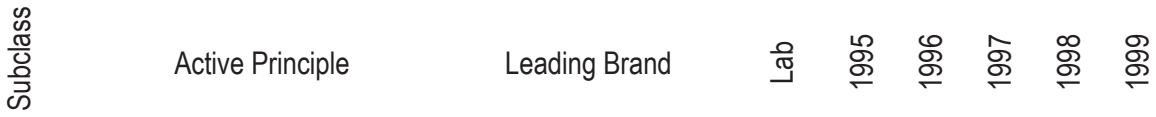

\begin{tabular}{|c|c|c|c|c|c|c|c|c|}
\hline C05BO & Polysulfuric & HIRUDOID & SKY & & 1.00 & 1.00 & 1.00 & 1.00 \\
\hline P01B0 & Albendazole & ZENTEL & SB- & 0.50 & 0.42 & 0.40 & 0.38 & 0.33 \\
\hline J01C1 & Amoxicillin & AMOXIL & SB- & 0.44 & 0.42 & 0.46 & 0.43 & 0.41 \\
\hline C07A0 & Atenolol & ATENOL & ZNC & 0.79 & 0.77 & 0.74 & 0.72 & 0.62 \\
\hline J01F & Azithromycin & ZITROMAX & PFZ & & 1.00 & 0.55 & 0.31 & 0.23 \\
\hline CO8AO & Amlodipine Besylate & NORVASC & PFZ & 0.89 & 0.77 & 0.74 & 0.73 & 0.72 \\
\hline CO9AO & Captopril & CAPOTEN & BMS & 0.87 & 0.89 & 0.85 & 0.82 & 0.71 \\
\hline N03A0 & Carbamazepine & TEGRETOL GEIGY & NVR & & 1.00 & 0.99 & 0.98 & 0.96 \\
\hline J01D1 & Cefalexin & KEFLEX & LLY & 0.96 & 0.94 & 0.94 & 0.89 & 0.78 \\
\hline J02A0 & Ketoconazole & NIZORAL & $\mathrm{J}-\mathrm{C}$ & 0.65 & 0.61 & 0.59 & 0.55 & 0.41 \\
\hline A03F0 & Cisapride & PREPULSID & $\mathrm{J}-\mathrm{C}$ & 0.66 & 0.61 & 0.50 & 0.46 & 0.41 \\
\hline $\mathrm{R} 05 \mathrm{CO}$ & Ambroxol Chlorhydrate & MUCOSOLVAN & B.I & 0.58 & 0.56 & 0.57 & 0.56 & 0.46 \\
\hline $\mathrm{A} 08 \mathrm{~A}$ & Amphepramone Chlorhydrate & INIBEX S & MY_ & 0.71 & 0.62 & 0.60 & 0.62 & 1.00 \\
\hline S01E2 & Betaxolol Chlorhydrate & BETOPTIC S & ALC & 1.00 & 1.00 & 1.00 & 1.00 & 1.00 \\
\hline J01A & Doxycycline Chlorhydrate & VIBRAMICINA & PFZ & 1.00 & 0.99 & 0.98 & 0.90 & 0.80 \\
\hline N06A0 & Paroxetine Chlorhydrate & AROPAX & SB- & 1.00 & 1.00 & 1.00 & 0.95 & 0.80 \\
\hline A02B1 & Ranitidine Chlorhydrate & ANTAK & GWC & 0.26 & 0.27 & 0.27 & 0.27 & 0.26 \\
\hline N04A0 & Selegiline Chlorhydrate & NIAR & KNO & 0.35 & 0.37 & 0.39 & 0.40 & 0.41 \\
\hline С03A3 & Chlortalidone & HIGROTON GEIGY & NVR & 0.98 & 1.00 & 1.00 & 1.00 & 0.99 \\
\hline D03A0 & Dexpanthenol & BEPANTOL & $\mathrm{ROC}$ & 1.00 & 1.00 & 1.00 & 1.00 & 1.00 \\
\hline M01A1 & Potassium Diclofenac & CATAFLAM GEIGY & NVR & 0.83 & 0.85 & 0.86 & 0.87 & 0.84 \\
\hline R01A1 & Beclometasone Dipropionate & BECLOSOL AQUOSO & GWC & 0.82 & 0.74 & 0.72 & 0.72 & 0.68 \\
\hline $\mathrm{A} 13 \mathrm{~A} 2$ & Panax Ginseng & GINSANA & B.I & 1.00 & 1.00 & 1.00 & 1.00 & 1.00 \\
\hline G04B2 & Finasteride & PROSCAR & MSD & 0.72 & 0.59 & 0.52 & 0.50 & 0.40 \\
\hline $\mathrm{A} 10 \mathrm{~B} 1$ & Glibenclamide & DAONIL & HMR & 0.91 & 0.93 & 0.93 & 0.94 & 0.92 \\
\hline $\mathrm{R} 06 \mathrm{~A} 0$ & Loratadine & CLARITIN & $\mathrm{SHC}$ & 0.99 & 0.93 & 0.86 & 0.77 & 0.70 \\
\hline $\mathrm{N} 05 \mathrm{CO}$ & Lorazepam & LORAS & WYE & 0.91 & 0.94 & 0.93 & 0.93 & 0.93 \\
\hline $\mathrm{C} 02 \mathrm{~A} 1$ & Methyldopa & ALDOMET & PDM & 0.99 & 0.98 & 0.98 & 0.96 & 0.88 \\
\hline J01G1 & Norfloxacin & FLOXACIN & MSD & 0.43 & 0.40 & 0.39 & 0.36 & 0.31 \\
\hline C04A1 & Pentoxifylline & TRENTAL & HMR & 0.94 & 0.93 & 0.92 & 0.90 & 0.84 \\
\hline $\mathrm{D} 10 \mathrm{~A} 0$ & Benzoyl Peroxide & SOLUGEL & STF & 0.63 & 0.57 & 0.53 & 0.54 & 0.60 \\
\hline $\mathrm{H} 02 \mathrm{~A} 2$ & Prednisone & METICORTEN & $\mathrm{SHC}$ & & 0.99 & 0.97 & 0.95 & 0.89 \\
\hline C01E0 & Propatylnitrate & SUSTRATE & BMS & 1.00 & 1.00 & 1.00 & 1.00 & 1.00 \\
\hline D07A0 & Clobetasol Propionate & PSOREX & GWC & 1.00 & 1.00 & 1.00 & 0.99 & 0.98 \\
\hline R03A1 & Salbutamol & AEROLIN & GWC & 0.96 & 0.96 & 0.97 & 0.96 & 0.97 \\
\hline G01A1 & Secnidazole & SECNIDAL & RHD & 1.00 & 0.89 & 0.75 & 0.48 & 0.33 \\
\hline $\mathrm{C} 10 \mathrm{~A} 1$ & Simvastatine & ZOCOR & MDS & 1.00 & 1.00 & 0.85 & 0.76 & 0.69 \\
\hline D08A0 & Thiomersal & MERTHIOLATE & LLY & 1.00 & 1.00 & 1.00 & 1.00 & 1.00 \\
\hline $\mathrm{D} 01 \mathrm{~A} 1$ & Tioconazole & TRALEN & PFZ & 1.00 & 1.00 & 1.00 & 1.00 & 1.00 \\
\hline М03В0 & Tizanidine & SIRDALUD & NVR & 1.00 & 1.00 & 1.00 & 1.00 & 1.00 \\
\hline
\end{tabular}


For the present status of the pharmaceutical industry, a lot has been contributed by researches in chemically based pharmacology and by the startup of production in industrial scale of chemically isolated substances resulting from those researches. Since the first patent was granted to a pharmaceutical product in the 1940s, the innovating firms turned to patents to restrict access to production and commercialization of their products and thus became able to monopolize temporarily their market. The temporary monopoly of the product is important for the innovating firm to assure a captive market that will later perceive a cost (if subjective) in experimenting a competing generic version and substitute it for the original brand when the patent expires. During this monopolistic period, the innovating firm is able to extract rents that will remunerate its initial investments in Research and Development $(\mathrm{R} \& \mathrm{D})$ on that product and on so many others that did not succeed therapeutically or commercially.

The fast pace of development of new medicaments imply in profound variations of market leadership. Many drugs that are current market leaders in their therapeutic classes simply did not exist ten years ago. The introduction of a revolutionary innovation may propel a laboratory to a leading role in the industry in no time. Thus, the industry may be characterized by an infinity of overlapping product life cycles composed of three phases in each market: ex-ante there is a lot of competition among the laboratories, especially for R\&D investments; after this Darwinian competition for new products, a few successful products remain, each of whom enjoys in the meantime a monopoly in the stricter market of the Active Principle - but face competition of other substances directed to diseases in common (some of these substances having been introduced shortly after or before, and with very similar molecular structures); at this stage of monopoly of the substance, the firm's market power increases as the drug is gradually disseminated among the doctors. Finally, when the patent expires, direct substitutes (generic copies) emerge, that raise the market competition level.

The patent plays a fundamental role in the dynamics of the pharmaceutical industry. Levin et al. (1987) found in interviews with executives of 130 industries that the pharmaceutical industry was the one where patents were the most effective means to protect and appropriate returns from innova- 
tions on products and processes - but mainly on products. Mansfield (1986) sent questionnaires to 100 randomly selected firms in 12 manufacturing industries in the USA and concluded that without patents the pharmaceutical industry would be the most affected in failing to introduce the greatest number of products between 1981 and 1983. Protection is more effective on the pharmaceutical product than on the manufacturing process, as compared, for instance, to the electronic industry, because the object of the product patent is the molecule itself or a combination of molecules, whereas a same function in an electronic equipment may be emulated by different devices. The product is more effectively protected than the process because a same drug may be produced using several different chemical processes. (NOGUÉS, 1990).

Given the focus of patents on the chemical compound, the high number of innovations since the 1940s (peaking 54 in 1957, but contracting to half as much in the following decades) is not surprising. ${ }^{2}$ Actually it is questionable how many of the "innovations" recorded in the industry really pose new benefits to the consumers (PEPE \& VERAS, 1995), but the debate is far from a consensus. ${ }^{3}$ At any rate, it is not an overstatement to assert that the strategy of introducing new products, rather than a concern of the laboratories in treating more and more diseases, is a spatial market preemption strategy, aiming at foreclosing all the possible market niches to potential entrants by occupying them first. ${ }^{4}$

2 Still, the evidence on causality from intellectual property enforcement to innovation is far from conclusive; actually some papers point out to the opposite direction of causality. See, for example, the article by SAKAKIBARA \& BRANSTETTER (2001) and the literature cited in their conclusions.

3 For example, PELTZMAN (1973) utilized U.S. data and estimated that the cost of preventing ineffective drugs from entering the market was two to four times greater than the benefits that would accrue if more medicaments were approved and more rapidly. LICHTENBERG (1996a, 1996b, 1998, 2001) estimated the contribution of pharmaceutical innovation to consumer welfare through reductions in mortality, morbidity and total medical expenditure. In all papers, Lichtenberg found large gains to consumers.

4 For more details on this kind of strategy, see TIROLE (1988, p. 282-285). 
Another important feature of the pharmaceutical industry is that its products are meant to treat diseases, so that an ineffective drug may pose the risk not only of being too expensive for its quality, but also of causing an adverse reaction (a side effect, another disease or even the patient's death). The drug may also be completely ineffective for the patient's recovery, either because he/she took the wrong medicine or in a wrong dosage, or simply because no adequate drug exists for his/her case.

Given that the market is unable to regulate itself, because of market failures to be discussed in the next section, the governments called upon themselves the responsibility of controlling medicaments available in the market. In the USA, the legislation on drug safety evolved in response to tragedies caused by unsafe drugs. Time spent by the FDA (Food and Drug Administration) to approve a new drug rose from a maximum of 60 days in 1938 to an average of 14 months in 1963 and to an average of 37 months in 1986. Facing the increasing rigor of the Agency on safety concerns, and due to the increasing difficulty in creating drugs that signified cost and effectiveness advance, the total development time of new drugs also grew. As the laboratory had to apply for the patent and, at the same time, submit the substance to the FDA's screening, the net patent coverage time was sacrificed until the approval was issued. On the other hand, generic substitutes faced the same tests imposed on the pioneer drugs, and this delayed original patent effective protection.

The Patent Restoration Act (also known as the Waxman-Hatch Act) worked twofold: on the one hand, it restored part of the patent lifetime lost because of the FDA tests lengthened by a 1962 Act; on the other hand, instead of replicating the pioneers' tests, the generics had only to pass the bioequivalence test. Thus, the Act pleased innovating companies by extending the patent lifetime and at the same time reduced enormously the lag between patent expiration and competitors' entry.

Not only does the rigorous process of approving drugs by the competent agencies require costly testing in human beings, but also the great majority of market niches have been little by little occupied by the several innovations along the years. Adding things up, this has raised significantly the cost of 
development of new substances: in the 1980s it varied between 140 and 280 million dollars (DIMASI et al., 1991); in the 1990s, it amounted to as much as 350 million. (FAGAN, 1998). R\&D expenditures' share in firms' revenues rose as well: in 1970 it was 8 percent; in 1980, it had reached 11.9 percent; in 1996 it was already 13.5 percent; and in 2000 it topped 20.3 percent. (RUPPRECHT, 1999; PhRMA, 2000). Greater and greater scale and scope economy requirements in research lines have also induced many laboratories to seek joint ventures, mergers and acquisitions. ${ }^{5}$

Generic drugs' competitive entry and their rapid diffusion, thanks to health plans' and regulatory agencies' pressure, have also shortened the product's effective monopolistic period and thus placed more pressure on the laboratories for new discoveries.

\subsection{Informational Asymmetries in Demand for Medicaments}

To better understand the nature of the market for prescription drugs and the existing barriers to entry in it, it is convenient to make use of a classification of consumption goods according to the consumers' ability to observe its quality attributes before or after its purchase. Thus, if this quality may be learned before purchase, the good is called a search good - this is the case of clothing, music albums, among others. If the quality can be verified only after it is bought (e.g. canned food, restaurant food), it is named an experience good. ${ }^{6}$ In other cases, the consumer may never be able to evaluate some aspects of the quality of the good; such goods have been christened credence goods ${ }^{7}$ because only a qualified professional is able to deliver this evaluation and certify them. This is the case of mechanic services, medical services, content of fluoride in a toothpaste, and even the nutrition facts of a ready-to-eat breakfast cereal.

5 From 1985 to 1998 the pharmaceutical industry recorded 37 mergers and acquisitions above US\$ 500 million.

6 Both names were coined by NELSON (1970).

7 See DARBY \& KARNY (1973). 
Lack of knowledge of a good's quality and the inexistence of a certification authority and/or legal norms and procedures to guide the certification process create an important informational asymmetry and give the pioneer brands an advantage over the potential new entrants: once the brand's reputation has been established, the consumers are reluctant to leave it for another one whose quality has not been verified, either by an authoritative agency or by a long period of market acceptance. Without this certification, new or almost unknown brands of similar products have difficulties in penetrating the market because of the enormous marketing costs needed. This natural barrier to entry may be removed or softened in two alternative ways: (i) through a deliberate action by the government in providing quality certification; (ii) through the competitors' private action, replicating the information diffusion effort (combined with advertising) when introducing a new brand.

Prescription drugs fit perfectly the credence good description. Its purchase depends on the handing of a medical prescription. The physician is the choice maker and faces an increasing set of active substances, whose efficacy and safety are imperfectly known to him. His choice is conditioned by a list of factors, among them the education level and habits of the population, contents of the medical school courses, government regulation and the pharmaceutical industry's actuation, both in $\mathrm{R} \& \mathrm{D}$ and in marketing. (HEMMINKI, apud PEPE \& VERAS, 1995). The lack of fluid, organized and consolidated information comparing the effectiveness of the available drugs in the market is a serious obstacle to a well-grounded appraisal of the physician on what medicament to prescribe, thus magnifying the effect of the pharmaceutical industry's actuation. In other words, information fluidity is as important or more than its mere existence.

Hence, the physician's decision process can be divided into two stages, each one involving a type of informational asymmetry: 
1. The physician chooses the most effective and safest treatment for the patient based on his academic background and professional experience, or on his peers' experience, on his own learning in congresses, readings of medical journals or on his networking. However, Temin (1980), Hellerstein (1994) and Berndt et al. (2000) point out to the predominance of a behavior whereby prescription occurs out of habit or inertia. Diffusion of a medicament's consumption generates informational externalities to the doctors, and it is fair to say that their prescription habits follow a typical pattern of herd behavior. (BERNDT et al., 2000). Choice of treatment, including the occasionally prescribed medicament, defines the INTERSUBSTANCE COMPETITION, that is, competition between different active principles.

2. The medicament can be described in three different ways: by the chemical name of the molecule; by the medical or generic name; or by the fantasy name, corresponding to the reference brand, i.e., the brand adopted by the patent holder, and to the brands created by imitators. Sales promotion uses to emphasize the fantasy name. The physician may prescribe the fantasy name or the generic name. Here is the INTRASUBSTANCE COMPETITION defined between the proper branded product and the generic and similar drugs. The informational asymmetries are twofold: the physician ignores the prices of the generic drugs and has reservations regarding their quality as compared to the reference product. Technically speaking, this comparison is defined by the following concepts:

(i) Bioavailability: how much of the active principle is absorbed by the blood flow, where and how much it works therapeutically; ${ }^{8}$

(ii) Pharmaceutical equivalence: Pharmaceutical Equivalents "are drugs containing the same salt or ester of the same therapentically active molecule, in the same pharmaceutical quantity and state, and which may have identical excipients or not. They must comply with the same up-to-date specifica-

8 According to Resolution n. 84 of the National Health Surveillance Agency (March 19, 2002), bioavailability "indicates speed and extent of absorption of an active principle in a dosage form from its concentration/time curve in his/her systemic circulation or in his/her excretion in the urine." 
tions of the Brazilian Pharmacopeia, and in the absence of them, with the specifications of other regulations authorized by the legislation in effect, or yet with other applicable quality standards, related to the identity, dosage, purity, power, content uniformity, half-life and dissolution speed, when it is the case." (ANVISA - NATIONAL HEALTH SURVEILLANCE AGENCY, Resolution n. 84, March 19, 2002).

(iii)Therapeutic equivalence: "two medicaments are considered therapeutically equivalent if they are pharmaceutically equivalent and, after administrating the same molar dose, their effects with respect to effectiveness and safety are essentially the same - and this is evaluated through appropriate bioequivalence studies, pharmacodynamical tests, clinical tests or in vitro studies..." (ibidem).

Two drugs are bioequivalent if they are therapeutically equivalent and have the same bioavailability. ${ }^{9}$ As we note on item (ii), two drugs may be pharmaceutically equivalent and comply with quality standards, but this does not mean that their quality is the same.

A quality certification policy would thus have a role of signaling information to professionals so as to correct two levels of informational asymmetry in distinguishing effectiveness and safety: of active principles among each other, and between the reference drugs and the generics of the same active principle. It should also signal to doctors and to the population that the manufacturing conditions comply with minimum quality standards. And, most important, it should consolidate this information, for instance in official therapeutic guides, so that the physician would have all the elements in order to compare effectiveness and safety of drugs with each other. Lack of this information gives room to the laboratories to provide information for their own benefit, distorting the quality signals in the market.

9 More precisely, bioequivalent drugs "are pharmacentical equivalents that do not present statistically significant differences with respect to bioavailability when they are administrated in the same molar dosage." (ibidem). 
It is worth noting that even after the original patent expires, the original patent holder loses the monopoly of the drug, but not of the brand, therefore it is in the interest of the firm to promote the brand, as promoting the substance ends up generating positive informational externalities (spillovers) in favor of the generic suppliers. ${ }^{10}$ To some extent, it is hard for the professionals themselves to distinguish quality dimensions related to the substance from those dimensions that separate reference drugs and generic drugs. The consequent uncertainties create a quality differential perceived by the agents, which is appropriated by the leading firm by charging a higher price associated to the brand. In case the drug's patent is not enforced (as it was indeed the case in Brazil from 1969 to 1998), brand promotion becomes even more important, since the laboratory has to differentiate its product from early competitive entrants. ${ }^{11}$

It is true that the entrants can replicate sales promotion expenditures when introducing new brands. In the case of the intra-substance competition, this cost should even be lower than the one incurred by the pioneer, because the doctor already knows the substance and its therapeutic properties, and it is up to the firm to persuade him of the equivalence - the pioneer would thus be internalizing the cost of certification (the tests above mentioned and any other applicable ones), which would convey the same information to the doctor. But it is important to note that this cost is as sunk as the pioneer's cost; now, once the pioneer's sunk cost has been incurred, it is irrelevant for his later behavior, while the entrant's sunk cost defines the latter's strategy

10 Advertising becomes more persuasive, in detriment of its informational character, according to HURWITZ \& CAVES (1988) and LEFFLER (1981). Still, in countries where patents are enforced, it is noted that advertising and promotion expenditures are concentrated in the first years right after introduction and, as the patent expiration draws close, these expenditures decrease quite quickly. Although we do not have data to prove, we can conjecture that the trajectory of the expenditure level is smoother along time where patents are not enforced. Though it may sound a contradiction that advertising expenditures are lower at the end of the patent lifetime - when the laboratories should be reinforcing such expenditures - we should stress once more that in the presence of a signal for the consumption decision makers that the generic drug is bioequivalent to the pioneer drug, the substitutibility perceived by those agents is far greater; therefore investments in advertising and detailing are much lower. This seeming contradiction is resolved by noting that there are two factors that are distinct but use to occur jointly: the patent enforcement and the formal acknowledgement of bioequivalence between the pioneer and the generic drug.

11 Executives of the laboratories themselves admitted this behavior in informal discussions at Seae, an office of the Ministry of Finance in charge of the economic evaluation of mergers and acquisitions and other antitrust cases. 
when entering. Even if we do not assume that the cost is sunk, the intangible asset created by investment in the brand (a goodwill stock for the brand) is already given for the pioneer, as opposed to the entrant.

Another issue in the pharmaceutical market besides the credence good nature of the product is that there is a distinction between who makes the choice of the medicament (the doctor) and who consumes it (the patient). In addition, who pays for the medicament may be the patient (the most common arrangement in Brazil) or a third party, such as a public health system (most common in Europe and Japan) or a private health plan (most common in the USA). This separation between the choice maker and the payer can be represented in Economic Theory as an agency problem (moral hazard): the Principal (the patient) wants to maximize his/her expected utility, which takes into account not only the probability of the state of the world where the patient enjoys good health, but also the expenditures of the treatment, in case the patient becomes ill. The agent (the doctor) should do this calculation, but he/she is more concerned with maximizing the patient's health (or at least minimize the risk of damage to the patient's health and consequently the risk of a lawsuit) and not necessarily will be bothered by the amount to be spent on the prescription. ${ }^{12}$ Even if he/she does not bother about the patients' health, he/she will hardly worry about the expenditure if it is reimbursed by a health plan. ${ }^{13}$ Moreover, the required information on relative prices demands some (costly) effort from the doctor. ${ }^{14}$

12 The modeling of this sort of behavior can be found, among other sources, in LISBOA \& MOREIRA (2000). If the payer of the treatment is a public or private health plan, two levels of Principal-Agent relationship overlap: besides the relationship mentioned above, another one is between the health plan as the Principal, aiming at maximizing profits, and the patient as the Agent, with the same utility function mentioned earlier. For the sake of our present empirical exercise, however, this distinction is irrelevant, as we remind the reader that the drug coverage by health plans is virtually absent in Brazil.

13 HELLERSTEIN (1994) supports this argument by reporting that the average expenditure of the patients without any coverage was US\$ 212 in 1987; whereas the average expenditure of Medicare members (also without coverage) was US\$266, and of the (covered) Medicaid members was US\$ 399.

14 HELLERSTEIN (1994) mentions a case study where a home delivery pharmacy service, Medco, contacts physicians and try to persuade them to substitute generics for the actually prescribed drugs; their success rate varied between 25 and 30- percent of the tries. This demonstrates the willingness of physicians to be price sensitive when adequate information about price and efficacy is provided to them. 
Actually, the distinction between payer and patient has three dimensions: on the one hand, when the payer is the patient, the latter can place a more direct pressure on the doctor to have a cheaper medicament prescribed; on the other hand, a health plan or public health service works as an insurance, which smoothes the individual expenditure path along time and, in addition, has a larger information set on the existence and relative price of available generic drugs to replace the prescribed drug. The net effect of these three factors is uncertain. But a point is that, in the absence of clear rules of substitution of generics for branded drugs (what in turn presuppose quality certification) and an efficient surveillance of drug sales in drugstores and pharmacies, substitution of prescribed drugs is subject to the discretionary power of patients and pharmacists.

As a result of the ever-increasing costs of the innovative drugs by firms in the industry, combined with the difference in objectives between Principal (patient) and the Agent (physician), the share of expenditures on drugs in the households' budgets have grown and motivated a great number of changes in the regulation of the pharmaceutical sector and of health expenditure systems in several countries. One of the main strategies on hands of the regulators to bring the drug prices down is the promotion of generic drugs. Experiences of inducing substitution of generics for the originally patented brands after patent expiration vary among countries. In the USA, this subject have been dealt with by specific state legislations that have been gradually modified, either to allow the pharmacists to dispense a medicament other than the one prescribed by the doctor or even to obligate them to dispense the generic regardless of the version prescribed, unless the doctor rules it out in the prescription.

The approaches of Western European countries, where most of the citizens are reimbursed by public health services, have been to place boundaries on expenditures and to spread information by: 1) creating very strict lists of drugs subject to reimbursement (the so-called positive lists); 2) establishing reference prices, price controls or price reduction agreements with the industry; 3) designing prescription guidelines; 4) inducing substitution of generic for branded drugs; 5 ) creating prescription budgets for individual doctors, groups and regions; 6) requiring co-payments. Thus, in a way or another, incentives are sought for doctors and patients to economize in 
prescriptions. In the USA, this kind of policy is implemented by private insurers (health plans, HMOs and PBMs) instead of the public system.

\section{EXPENDITURES ON PHARMACEUTICAL DRUGS IN BRAZIL}

\subsection{Evolution of Protection Policy to Pharmacentical Industry}

In Brazil, the legislation did not recognize patents of chemical-pharmaceutical products as from 1945. In 1969 the recognition of process patents was also suspended, and this situation prevailed until 1996, when a new Patent Act was passed under a severe pressure of developed countries before the WTO (World Trade Organization), covering both products and processes. During the process-patent-free period several attempts were made to develop indigenous process technology in the pharmaceutical industry by the national-development wing of the military regime every time -they took the presidency of CEME, the Medicament Distribution Authority. ${ }^{15}$

CEME's autonomist project did not resist, however, to the internal contradictions of the military regime, which alternated in its managing posts technocrats and politicians in line with opposing views about the role of the State in providing medicaments to the population, thus causing a strong discontinuity in its supporting activity. The autonomist project was then severely harmed during President Collor's term: as trade was liberalized in 1990 and market protection was phased out, very few laboratories kept their production capacity with some vertical integration. ${ }^{16}$ In 1996 the new Patent Act was passed and enacted, in response to the pressures for TRIPs

15 CEME became the symbol of failure of a Brazilian attempt to replicate the experience of other countries that, according to BERMUDEZ (1992), made use of the absence of patents to develop strong pharmaceutical industries and only recognize patents once they acquired competitiveness. The author cites names, such as the United Kingdom, Italy, Spain, Japan and France.

16 Local production dropped from 60 percent of the market in 1987 to 18 percent in 1998. (QUEIROZ \& GONZÁLEZ, 2001). 
(Trade Related Intellectual Property agreements) placed during the Uruguay Round. This new law ended up tearing down the project of technological autonomy. The perverse side of the consequent vertical disintegration of the pharmaceutical industry is that pharmaceutical intermediate imports have served the interests of Multinational Corporations in practicing transfer pricing: by inflating import prices, not only the internal costs are inflated and the branches' profits are artificially reduced (and so are taxes levied on them), but also royalty remittances to the headquarters (and their respective taxations) are avoided. ${ }^{17}$

It is worth noting that the domestic active principles were not subject to tests of bioequivalence to the reference drugs', rather they were approved according to international standards. Drugs based on both domestic and imported substances by those producers had typically only the bioavailability approved. The so-called Generic Drugs Act of 1999 names this type of drug a similar drug, which is obliged to adopt a fantasy name (instead of the generic name) so as not to free ride the public campaigns in favor of the use of generics - otherwise the drug must be submitted to the bioequivalence test. In addition, the pharmacist is also subject to legal penalties if he dispenses a similar drug (instead of a generic) in substitution for the reference drug. It becomes more difficult thus to deceive the consumer alleging that the drug is generic because it bears the generic name (besides the fact that the generic can be recognized by a special label provided by the Ministry of Health). And in case the similar drugs are really bioequivalent and do have quality, or in case it does not cost so much to adequate them to the required specifications, their manufacturers will benefit from publicity

17 SILVA (1999) cites a true story, where a given substance, identified by a fake name hypertensil, was imported from the headquarter to a local branch of a multinational corporation. The Import Tax rate was just 2 percent for that substance, while the Income Tax rate was at most 25 percent, besides the Contribution on Net Profit (10 percent). It is clear that it paid to the multinational to practice inflated transfer prices in this case, which is probably not an isolated example: the maximum rate applied on the import good codes referring to pharmaceuticals and chemicals (sections 28 to 31 ) was 41 percent only for five months in the beginning of 1998 , and remained below 20 percent during 33 months from January 1995 to December 1998. 
on generics, availability of lists of generics, etc. (made by the Ministry of Health) if they pass the tests, thus saving advertising and detailing costs and compensating for the tests' costs.

\subsection{Recent Evolution of Drug Prices and Firms' Profits}

According to the Household Expenditure Survey (named POF after its Brazilian acronym) wave ran by IBGE (the Brazilian Bureau of the Census) in 1987-88 and utilized to calculate the consumption bundle of the National Consumer Price Index System, the share of pharmaceutical products in the budgets of families with earnings between 1 and 40 minimum wages in October 1987 was 2.55 percent. In September 1996, according to the second POF wave (run in 1995-96) this item's share had risen to 3.55 percent. Moreover, based on the first POF wave's weighting structure, the prices of the pharmaceutical products- group rose 116.52 percent from July 1994 (date of the Real Plan) to October 2000, whereas the general index rose 94.60 percent only.

Graph 2.1 depicts the evolution of pharmaceutical prices relative to the consumption bundle in the 1990s. The relative prices increased considerably, especially in 1992-93, following the end of drug's price control. That moment of margin recovery set up a new price base level, very much above the one in effect during the 1980s. From 1994 to 1995 the base level was lowered (though still above the level of the previous decade), probably due to a fall of imported raw material cost after the appreciation of the Real, and this was followed by a period of relative stability (finished in 1999 with the depreciation of the Real). 


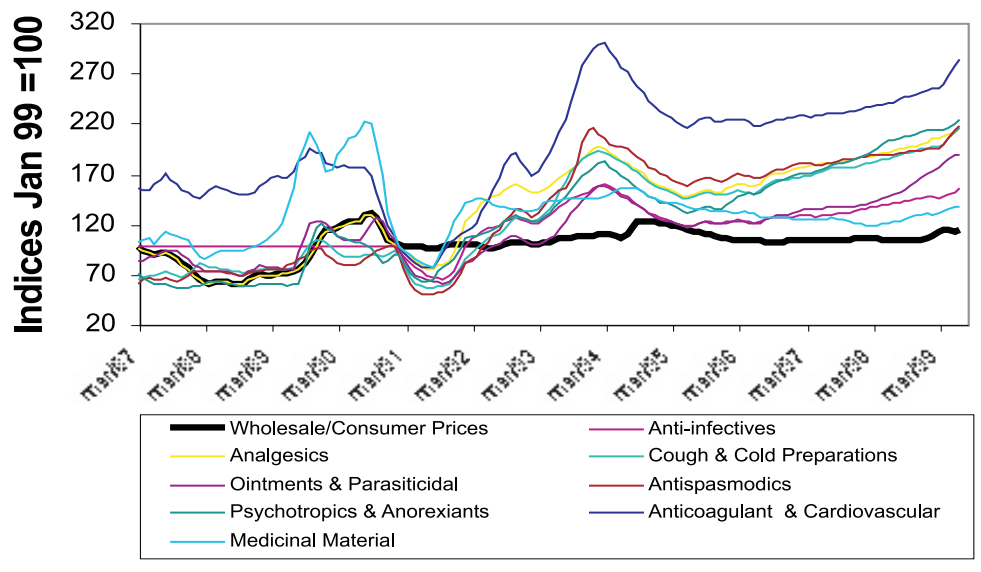

Source: IBGE and IBRE/FGV. Prices of the various sub-items are measured as sub-item/general index ratios.

Table 2.1 displays the pharmaceutical industry's profitability in the 1990s. The industry's profitability followed a cyclical behavior in the same period, that is, it increased in the first four years and decreased from $1997 \mathrm{on}$. The early 1990s were marked by a comprehensive process of unilateral trade liberalization and by high inflation rates. Liberalization may have had a positive impact on average prices, leading to the industry's profit increase. However, the high inflation rates of the period renders a conclusive analysis of the balance sheets in that period very difficult, as tax law distortions favored negative net outcomes, and inflation facilitated these outcomes.

From 1994 on, upon the successful stabilization program Real Plan, the outcomes are as expected. Right after the Real Plan was launched, the exchange rate was severely appreciated and the real disposable income went up, so the import costs went down and the average profitability increased. The succession of external crises, in particular from 1997 on, the accelerating depreciation of the exchange rate, and the economic contraction brought forth a visible decrease to the industry's profitability, especially in 1999, when the laboratories refrained from raising prices after an agreement with the Federal government. 
TABLE 2.1 - PHARMACEUTICAL INDUSTRY'S PROFITABILITY

\begin{tabular}{ccccc}
\hline \multicolumn{5}{c}{ Weighted Average (in percentage) } \\
\cline { 2 - 5 } & $\begin{array}{c}\text { Net Profit / } \\
\text { Total Assets }\end{array}$ & $\begin{array}{c}\text { Net Profit / } \\
\text { Equity }\end{array}$ & $\begin{array}{c}\text { Net Profit / } \\
\text { Gross Sales } \\
\text { Revenue }\end{array}$ & $\begin{array}{c}\text { Net Profit / Net } \\
\text { Sales Revenue }\end{array}$ \\
\hline 1990 & $-1,90$ & $-4,51$ & $-2,31$ & $-2,86$ \\
1991 & $-3,17$ & $-5,25$ & $-5,63$ & $-6,64$ \\
1992 & 3,86 & 5,98 & 7,41 & 8,61 \\
1993 & 5,44 & 7,45 & 10,79 & 12,74 \\
1994 & 17,71 & 24,38 & 19,33 & 23,19 \\
1995 & 10,33 & 14,76 & 9,28 & 11,14 \\
1996 & 13,99 & 21,61 & 11,07 & 13,42 \\
1997 & 12,01 & 18,05 & 7,64 & 9,90 \\
1998 & 11,80 & 18,42 & 7,78 & 9,99 \\
1999 & 8,06 & 15,34 & 5,52 & 7,16 \\
\hline
\end{tabular}

Source: Instituto Brasileiro de Economia (IBRE/FGV).

\subsection{Patient-Doctor Relationship in Brazil}

Even though it is a well-known trait of the Brazilian culture (and documented, for instance, by Loyola, 1984), self-medication appears not to be a quantitatively significant problem. An explanatory analysis of a special supplement of the Annual National Household Survey (PNAD, after its Portuguese acronym) on Health undertaken by Andrade and Lisboa (2001) tabulated the types of health care demanded by families that recalled a health problem in the recent past. Almost all families reported that looked for medical assistance when they manifested symptoms of some disease, regardless of income level and location. The poorest stratum (first decile) headed mostly to local public ambulatories - the percentage ranged from 50 percent (North) to 72 percent (South). In second place, this stratum went to other ambulatories (inside hospitals, clinics, working place or labor union facilities ) - the percentage varied between 18 percent in the South and 42 percent in the Northeast. Most of the rest went to an emergency room or to a private office. Only a little above 2 percent (average over all the income cohorts) reported having gone first to a pharmacy or other care providers - the percentage was higher for the sixth through eighth deciles. 
It is also worth noting that the shares of population that went to private office-based doctors increased approximately as much as the share that went to public ambulatories decreased, as we move up along the cohorts. For example, 66.06 percent of the first decile in the Southeast went to public ambulatories and 3.98 percent to private offices; in the tenth decile 6.03 percent- went to health stations and 64.26 percent to private offices.

\section{REVIEW OF EMPIRICAL LITERATURE}

As mentioned above, the physicians - the consumption decision takers - are in general regarded as having incomplete information on the drug options available for the treatment of various pathologies, in particular with respect to their cost. Therefore, no wonder that the initiative of providing information or even imposing controls on drug reimbursements arose in hospitals and health maintenance organizations (specifying, for example, a positive list, i.e., a list of prescribable generics). These firms reap scale economies (in transaction costs) in procurement and generic list making; therefore they seem to have most of the incentives to lower costs (e.g. hospitals paid through flat payment arrangements). In this sense, Frank and Salkever (1991) and Caves, Whinston and Hurwitz (1991) claim that the segment of the population uncovered by health plans tend to be less price-elastic, because neither the doctor nor the patient have complete information on the efficacy of lower cost drugs, and the former tends to prescribe on a customary basis. In addition, Leffler (1981) mentions that sales promotion expenditures for drugs mostly sold in pharmacies are much greater than the ones sold in hospitals, as the latter have enough scale to set up cost committees and compare cost-effectiveness of drugs.

However, competition from generic drugs takes place only when the leading brand's patent expires. Investments in sales promotion of these brands in general follow a pattern of high amounts right after introduction and decline as the expiration date draws near. An explanation is that the advertisement and detailing would have an expansive effect on the demand for the substance, and the generic products would benefit by free riding on 
them, so the laboratory that traded the drug's original brand would have a disincentive to invest in advertisement.

An important finding of Frank and Salkever (1995) is that generic drugs' entry gives rise to market segmentation: the incumbents prefer keeping prices elevated and catering to a more price-inelastic (brand loyal) market segment than lowering prices to defend market share against the generic drugs, who flourish in more elastic segments. In fact, in some cases the price of the original brand increases. Since the generic products gain market share, the net effect is a decrease of the average drug price in that market. The authors propose a model where branded drugs would behave like Stackelberg price leaders and generic drugs would be the followers, only that the latter would compete among themselves so as to reach a CournotNash price equilibrium.

Hurwitz and Caves (1988) studied the impacts of generic entry on market share, sales promotion expenditures and number of entrants in the USA and found that the brand's market share is directly proportional to its own age (this was interpreted as brand loyalty) and to sales promotion, and negatively correlated to the entrants' potential expenditures and to the number of entrants. The number of new entrants was directly proportional to the total size of the market and to the original brand's age. Grabowski and Vernon (1992) analyzed the impact of generic entry that followed the Waxman-Hatch Act. Like Frank and Salkever (1995), they found price increases for the branded drugs.

\section{MODEL AND DATA DESCRIPTION}

The present work aims to explain the drug price behavior in Brazil with market observed variables. In particular, we estimate the impact of the degree of concentration in each market on the leaders' prices and on the relative prices of similar and generic drugs, as well as the degree of dispersion of the latter. We are unaware of any previous study of this type in Brazil. 
Several econometric studies were made in the United States during the 1990s intending to study the impact of generic entry on prices of drugs whose patents had expired. In particular, the work of Caves, Whinston and Hurwitz (1991) illustrates the main aspects of the typical econometric approach used in that analysis. The authors selected a sample of thirty drugs that lost patent rights during the period 1976-87 and estimated the following equation for the branded drugs:

$$
p_{\mathrm{it}}=\phi_{\mathrm{i}}+\mu_{\mathrm{t}}+h\left(\mathrm{~A}_{\mathrm{it}} \mid \beta\right)+f\left(\mathrm{E}_{\mathrm{it}} \mid \gamma\right)+\varepsilon_{\mathrm{it}}
$$

where:

- $p_{\mathrm{it}}$ is the price variation (difference of $\operatorname{logs}$ ) of product $i$ in period $t$;

- $\phi_{i}$ is the product-specific unit cost;

- $\mu_{t}$ is a constant for the own marginal cost in period $t$;

- $A_{i t}$ are variables related to the time of exposure of the brand in the market;

- $\beta$ is the vector of parameters related to the elapsed time of exposure of the brand in the market, to be estimated;

- $E_{i t}$ are variables related to the degree of competition in the market for generic drugs;

- $\gamma$ is the vector of parameters — to be estimated — related to the degree of competition in the market for generics;

- $\varepsilon_{i t}$ is the error (unobserved variable);

The generic drugs had an equation of their own:

$$
\log \left(\frac{P_{i}^{G}}{P_{i}^{B}}\right)=\delta_{\mathrm{i}}+\left[g\left(\mathrm{E}_{\mathrm{it}} \gamma\right)-f\left(\mathrm{E}_{\mathrm{it}} \gamma\right)\right]+u_{\mathrm{it}}
$$

where:

- super-scripts $B$ and $G$ refer to brand and generic respectively;

- $P$ is price in level; 
- $\delta_{\mathrm{i}}$ is the quality differential of the generic as compared to the branded drug;

- $g$ reflects the fact that the entry of a generic can affect existing generic and branded drugs differently;

- $u_{\mathrm{it}}$ is the error (unobserved variable);

Adopting this approach for the Brazilian market should incorporate the specific features that distinguish it from the European and the American.

1) Inexistence of patent protection until 1998;

2) Existence of branded similar and unbranded similar drugs, in view of inexistence of generic product regulation, notably with respect to bioequivalence tests;

3) Predominance of imported raw material;

4) Inexistence of reimbursement for expenditure on drugs by private health plans or the government.

Items 1 and 2 imply that doctor and patient distinguish drugs mainly on the basis of how long they have been in the market and of sales promotion effort, since there is no unbiased signaling available from an official agency, such as a therapeutic guide. Item 3 suggests that the exchange rate and a reliable estimate of the cost of imported raw material would be good proxies for the cost of material of the products. Therefore, similarly to Caves, Whinston and Hurwitz (1991), we distinguish the leading drug only, which is the best selling brand - and usually the oldest brand available of that molecule - , but the age variables do not have a reference date related to a patent.

The data used in this study comes from a sample of sales from distribution companies to the retail drugstores and pharmacies - this highlights the importance of the fourth item, otherwise we would be studying a far smaller share of the demand, as the segment of great purchasers would have 
a greater weight in the total.. The therapeutic classification is the anatomical one, adopted by the World Health Organization, i.e., drugs are grouped according to the part of the body where they act - e.g. nervous, digestive, and respiratory systems, etc. Two difficulties arise from this classification: (1) there exist drugs of different Active Principles (or multiple APs) in a same class; (2) some drugs with different indications are present in more than one class. ${ }^{18}$

Thus, we resolved to adopt a market definition as restrict as possible: drugs based on a same substance (and only one substance) listed in the same class. Table 1.1 summarizes the therapeutic classes according to the Anatomic Classification. One-digit classes are subdivided into two-digit classes, and so forth down to the four-digit. Our sample selection went through the following steps: (1) we excluded products marketed mostly in clinics, hospitals, labs and emergencies (blood derivatives, hospital solutions, diagnostic agents and vaccines), because, as we mentioned in section 3, these segments face scale economies in processing comparative information on drugs, by appointing committees to select drugs also on the basis of cost-effectiveness, as opposed to the paradigm doctor-patient formerly pointed out, and end up displaying a higher sensitivity to prices; $(2)$ we selected the best-selling non-patented single-substance brand of each class (thus avoiding a mixture of very distinct markets); (3) we excluded subclasses with revenues below US\$ 30 million, or where all drugs were multi-source (e.g. vitamins); (4) we oversampled antibiotics and analgesics classes, given their high share in total revenues. The resulting initial sample, of 44 substances in 43 subclasses, was reduced later because of important missing information in some of them.

Once the substances had been selected, we searched on the Pharmaceutical Dictionary (Dicionário de Especialidades Farmacêuticas - DEF) all the drugs marketed in Brazil containing, each one, only one of the chosen substances.

18 Ideally we should obtain a sample of prescriptions grouped by pathology, so as to learn truly which drugs compete (are substitutes) to each other, and where. In case we could access such data (which we happen to know that exist), this would be a most interesting extension of the present work. 
For the estimated regressions, we tabulated only the revenues accruing from the version (e.g. pills, solution, etc.) with the highest share in that drug's total revenue, including different concentrations, as long as they could be prescribed for the same treatment. According to each drug's directions, capsules of different concentrations could be combined so as to add up to the prescribed daily treatment, and this was done the following way: the measure unit was the lowest concentration ratio; the others were rescaled by this ratio. On the one hand, this approach prevents comparing sales across imperfect substitute versions (with different routes of administration, e.g. applied through mouth, on skin or directly into the bloodstream); on the other hand, it does not distinguish packages of different sizes - this may represent a serious problem in Brazil, because the total dosage prescribed by the doctors is rarely an entire multiple of the box size, and this creates indivisibility problems that may affect the patient's purchase decision in an unknown fashion (perhaps the consumer chooses a smaller size, regardless of the dosage-adjusted price). Ruling out the latter problem, we regard as "price" the money amount per dosage unit (obtained by dividing total revenues of the version by the weight of the substance content).

We have also tried to match each drug with the respective sales promotion expenditure associated to the brand and with the imported raw material, obtained from the Brazilian Secretariat of Foreign Trade. In both cases, however, the apparent measurement errors were too many, so we decided to give up the attempt and to restrict ourselves to age and sales data. ${ }^{19}$

We have also tried to include the real exchange rate (according to the Purchase Power Parity - PPP) as a proxy of the imported raw-material cost. We believed that adding observations and eliminating measurement errors would compensate for the use of a macroeconomic variable, which

19 In particular, transfer pricing by Multinational Corporations and over-invoicing by domestic firms in the industry leaves to us no parameter of the real opportunity cost of imported raw material; moreover, many firms import raw materials through trading companies; last but not least, many substances are listed in too general import categories, along with other very different salts. As regards advertisement, the laboratories themselves complained that the available statistics from market survey companies are very far from their own private estimates; insufficient sample size and methodological imputation errors are potential explanations. 
is constant across all drugs. Moreover, that variable would reflect better the firms' global cost variations. However, the big exchange rate shock of 1999 introduced an excessive noise in the estimated effect of this variable; that noise translates into a forecast bias for the price behavior in 1999. We opted therefore for including only a dummy variable for the year 1999, which should capture the shift of the price floor resulting from both the exchange rate shock and the agreement between laboratories and the federal government to contain price raises (but may also capture other variables, as we comment below).

We rewrite then the model by Caves, Whinston and Hurwitz (1991) as:

$$
p_{\mathrm{it}}=\phi_{\mathrm{i}}+\rho_{\mathrm{i}} \cdot \mathrm{t}+M\left(B_{t} \mid \varphi\right)+h\left(A_{i t} \mid \beta\right)+f\left(E_{i \mathrm{t}} \mid \gamma\right)+\varepsilon_{i t}
$$

where:

- $M(\cdot)$ is a macroeconomic cost function, known up to the parameter vector $\varphi$;

- $B$ is a set of cost components common to all drugs in a same period $t$;

Also note that the drug's specific cost is assumed to have its own trend, so that the fixed effect is not completely eliminated by first differentiation of the function above. Differentiation is due to the disparity of price levels among drugs after being normalized to a common scale $(\mathrm{kg})$ - what motivates the different $\phi_{\mathrm{i}}$ 's -; moreover, our goal is to find a common behavior pattern.

Next, we differentiate (4.1a) in time and make linear approximations for the differences of $M(\cdot), h(\cdot)$ and $f(\cdot)$ functions. We proxy the first one with the industry's wage variation in the period, $w_{t}$. The second was approximated by a second-degree polynomial of the age logarithm, because, in conformity with the Product Life Cycle Theory, drugs may have their markets saturated from some point on. The third one was proxied by the market share variation, as the number of drugs did not change visibly during the period. The new equation is therefore the following for leading brands: 


$$
\begin{aligned}
& \Delta \ln \left(p_{g t}^{L}\right)=\left(\beta_{0}+\gamma_{1}+\varphi_{0}\right)+\beta_{1} \Delta \ln (\text { Share } Q Q)+ \\
& \gamma_{1} \ln (\text { Age })+\gamma_{2}[\ln (\text { Age })]^{2}+\varphi_{1} \Delta w+\varphi_{2} D_{-} 99+e_{g t}+\rho_{g}
\end{aligned}
$$

where:

- $p_{g t}^{L}=$ price per $\mathrm{kg}$ of leading drug based on substance $g$ in period $t$, in PPP Reais of 1999;

- $\Delta \ln ($ Share_Q $)=$ variation of logarithm of the firm's share in output of the market defined by substance $g$;

- Age $=$ number of elapsed years between introduction and observation years; this variable and its square are a polynomial approximation of the substance's product life cycle;

- $\Delta \mathrm{w}=$ percentage variation of wages in the pharmaceutical industry in Reais of 1999; it measures the variation of processing the substance domestically;

- D_99 = dummy equal to 1 in 1999; 0 otherwise; it measures the impact of government intervention in 1999, right after the devaluation of the Real, when an agreement was negotiated to contain the pass-through;

- $e_{g t}$ is a random error, i.i.d. along time and across groups.

The regressions were estimated both on the full sample (1995-99) and on a restricted sample (1995-99). Other macroeconomic variables, such as GDP and interest rate, were discarded because they showed a strong multicollinearity (correlation with each other and with other explaining variables, especially the exchange rate variation) - if not in the full sample, at least in the restricted period -, thus rendering impossible the matrix inversion for estimation. All the deflation procedures were undertaken by using the Broadened Consumer Price Index (IPCA), and when PPP was called for, by IPCA and the U.S. wholesale price index.

If we are not interested in the estimation of the $\rho_{g}$ as fixed effects (FE), we can model them as random variables, i.i.d. across groups but constant along time (random effects - RE). To decide between the two specifications 
(FE and RE) in each pair, we performed the Hausman test. (HAUSMAN, 1978).

Last but not least, it is important to note that the market share variation is a variable determined endogenously by the price variation, thus being correlated to the error. Therefore we instrumented it with the Herfindahl-Hirschman Index (as a measure of market concentration) of the corresponding substance in $\mathrm{t}-\mathrm{l}$. The estimates listed below were obtained by Instrumental Variables (actually Two-Stages Least Squares - 2SLS); in the RE case, the specific method adopted was Baltagi's (1981) Error Component 2SLS.

TABLE 4.1 - FIXED EFFECTS INSTRUMENTAL VARIABLE ESTIMATION

\begin{tabular}{|c|c|c|c|c|}
\hline & & \multicolumn{2}{|c|}{ 1995-99 Sample } & 995-98 Sample \\
\hline \multicolumn{2}{|c|}{ Number of observations } & 147 & \multicolumn{2}{|c|}{110} \\
\hline Number of substan & & 38 & \multicolumn{2}{|c|}{38} \\
\hline \multicolumn{2}{|c|}{ Average number of obs./drug } & $3 .-87$ & \multicolumn{2}{|c|}{$2 .-89$} \\
\hline \multirow[b]{2}{*}{ D_ln $\left(P^{\mathrm{kg}}\right)$} & \multicolumn{2}{|c|}{ 1995-99 Sample } & \multicolumn{2}{|c|}{ 1995-98 Sample } \\
\hline & Coefficient & t-Stat & Coefficient & t-Stat \\
\hline Constant & $-0,036370$ & -011454 & $-0,036010$ & $-0,09614$ \\
\hline D_Ln(Share_Q) & $-0,123320$ & -009966 & 0,269563 & 012472 \\
\hline Age & 0,005525 & 0.14031 & 0,007108 & 0.13960 \\
\hline$(\text { Age })^{2}$ & $-0,000600$ & -162400 & $-0,000420$ & -0.90345 \\
\hline D_W & 0,001353 & 1.35916 & 0,001200 & $\begin{array}{r}-0.90345 \\
088209\end{array}$ \\
\hline D_99 & $-0,177150$ & $-177351^{*}$ & & \\
\hline $\mathrm{R}^{2}$ & 0,89 & & 0,57 & \\
\hline $\begin{array}{l}\text { Joint } \\
\text { significance: }\end{array}$ & $F(6,103)=$ & $135,19^{* * *}$ & $F(5,67)=$ & $17,70^{\star * *}$ \\
\hline
\end{tabular}


TABLE 4.2 - RANDOM EFFECTS INSTRUMENTAL VARIABLE ESTIMATION

\begin{tabular}{|c|c|c|c|c|}
\hline \multirow[b]{2}{*}{$D_{-} \ln \left(P^{\mathrm{kg}}\right)$} & \multicolumn{2}{|c|}{ 1995-99 Sample } & \multicolumn{2}{|c|}{ 1995-98 Sample } \\
\hline & Coefficient & t-Stat & Coefficient & t-Stat \\
\hline Constant & $-0,05482$ & $-7.04367^{* * *}$ & $-0,080850$ & $-8,80281^{* * *}$ \\
\hline D_Ln(Share_Q) & $-0,26651$ & $-4.25489^{* * *}$ & $-0,330210$ & $-3,69308^{* * *}$ \\
\hline Age & 0,003774 & $4.78461^{* * *}$ & 0,006707 & $7,08845^{* * *}$ \\
\hline$(\text { Age })^{2}$ & $-5,53 \mathrm{E}-05$ & $-2.80928^{* * *}$ & $-0,000120$ & $-4,97809^{* * *}$ \\
\hline D_W & 0,001051 & $8.33806^{* * *}$ & 0,001004 & $8,78833^{* * *}$ \\
\hline D_99 & $-0,22035$ & $-23.05939^{* * *}$ & & \\
\hline $\mathrm{R}^{2}$ & 0,83 & & 0,52 & \\
\hline Joint significance: & $F(12,250)=$ & $209,08^{* * *}$ & $F(10,177)=$ & $37,53^{* * *}$ \\
\hline Hausman Test: & 15,27 & $\operatorname{Prob}\left(H>\varepsilon^{2}(5)\right)=0,01$ & 3,41 & $\operatorname{Prob}\left(H>\varepsilon^{2}(4)\right)=0,49$ \\
\hline
\end{tabular}

$\left(^{*}\right)$ Significant at 10- percent; $\left({ }^{* *}\right)$ Significant at 5- percent; $\left({ }^{* *}\right)$ Significant at 1- percent.

Note that the RE specification came out with more precise estimates than the FE, both in the full and in the restricted sample. Although the first (full sample) Hausman test rejected $\mathrm{H}_{0}$ the second one (on 1995-98) did not. As 1999 was an atypical year, due to the government's acute intervention, we understand that the sample until 1998 is more representative of what comes to be an intervention-free market equilibrium. Furthermore, RE's efficiency is greater when no evidence exists of correlation between explaining variables and unobserved individual effects. A priori, we should not expect to find such correlation, so we credit the rejection by the test in the full sample to the great difference of estimation caused by intervention. In view of that, we opted for the RE estimation. 


\section{GRAPH 4.1 - DIFFERENCE BETWEEN FORECASTED OR FITTED} AND OBSERVED VALUES

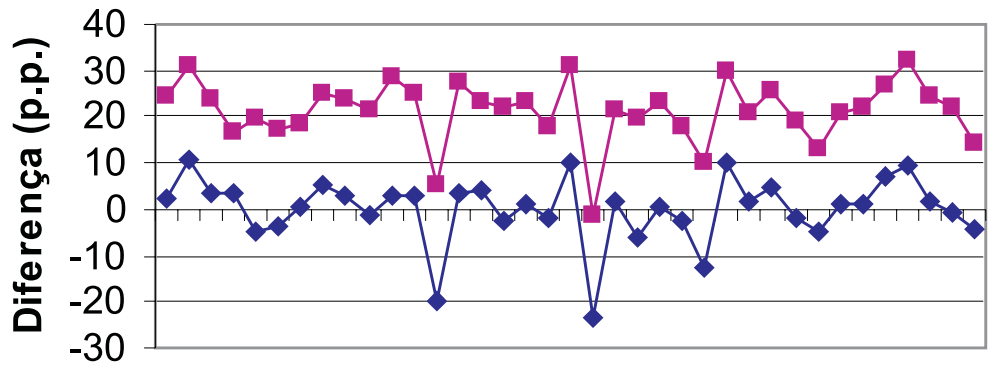

Marca

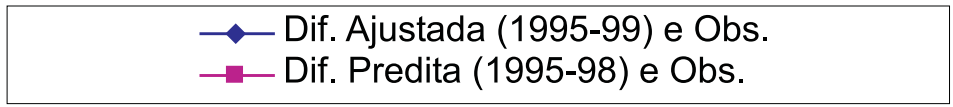

To have an estimate of the predictive power of our model, we present on Graph 4.1 the differences between the variations forecasted for 1999 (by the restricted sample RE model) and the observed variations in that year, and we find that on average the forecast overestimates the real variation in 21 percentage points, with a standard deviation of 7 p.p. This effect is in part due to the price agreement between the Federal Government and the manufacturers that occurred in 1999 - and the number is very close to the estimate of the D_99 dummy for the intercept (app. 22 p.p.) -, but can also be explained by indirect effects of the exchange rate realignment on the pharmaceutical market, especially the variations of GDP, interest rate and inflation, that could not be identified by the model; thus, in the absence of these effects, the agreement would be the only factor responsible for preventing drug prices from increasing 21 p.p. above the observed raise. Now, when we estimate the model to 1999 (still with RE), the expected fitted variation equals the average observed variation, that is, the bias is null - the standard deviation is 7 p.p. only.

Examining the estimates obtained, it is worth emphasizing that, as opposed to the common sense prediction - but in accordance with results obtained by the empirical studies reported in Section 3, the price of leading drugs raises more when the leading laboratory loses market share. This indicates 
that the laboratories alter their price fixing strategy when they lose room in the market, as they prefer catering to less price-elastic consumers and, therefore, collecting higher markups on lower volumes.

The age polynomial indicates that prices follow a typical product life cycle pattern; they grow more and more as the product becomes more known, up to a "maturation point", when the price raises finally decelerate and may become negative. It is worth noting that we cannot identify the intercept of the age polynomial, but only the sum of it to the other intercepts.

The interpretation above of laboratories' behavior is reinforced by another regression, also inspired in Caves, Whinston e Hurwitz (1991) - formula 45.2 above - where also the relationship between leader prices and followers' prices is given by the following equation:

$$
\Delta \ln \left(\frac{\bar{p}_{g t}^{S}}{p_{g t}^{L}}\right)_{g t}=\psi_{0}+\psi_{1} \cdot H H I_{-} Q_{g, t-1}+\psi_{2} \cdot H H I G_{-} Q_{g, t-1}+\psi_{3} l
$$

where:

- HHI_Q is the Herfindahl-Hirschman index of market output concentration; ${ }^{20}$

- HHIG_Q is another Herfindahl-Hirschman index, but excluding the leader - this index measures market share inequality among followers only;

- $\mathrm{t}_{\mathrm{Entry}}$ is the elapsed time in number of years since the entry of the first competitor of the pioneer brand;

- $\varepsilon_{\mathrm{gt}}$ is a random error;

- $\omega_{\mathrm{g}}$ is a time-invariant individual effect.

20 We utilized the lagged concentration index to avoid endogeneity and because it could not serve as an instrument, because it was too correlated to the dependent variable. 
TABLE 4.3 - FIXED EFFECTS LEAST SQUARES ESTIMATION

\begin{tabular}{|c|c|c|c|c|}
\hline & & \multicolumn{2}{|c|}{ 1995-99 Sample } & 1995-98 Sample \\
\hline Number of observations & & \multicolumn{2}{|c|}{109} & 80 \\
\hline Number of substances & & \multicolumn{2}{|c|}{31} & 29 \\
\hline \multicolumn{2}{|c|}{ Average number of obs./drug } & \multicolumn{2}{|c|}{3,52} & 2,76 \\
\hline \multirow[b]{2}{*}{$D \_\operatorname{Ln}\left(P^{\prime} / P^{L}\right)$ - Average } & \multicolumn{2}{|c|}{ 1995-99 Sample } & \multicolumn{2}{|c|}{ 1995-98 Sample } \\
\hline & Coefficient & t-Stat & Coefficient & t-Stat \\
\hline Constant & 0.0122 & 0.0650 & 0.0741 & 0.2266 \\
\hline$\left(H H I \_Q\right)_{t-1}$ & -0.1758 & -0.6145 & -0.2614 & -0.5292 \\
\hline$\left(H H I G \_Q\right)_{t-1}$ & 0.1575 & $1.7080^{*}$ & 0.1670 & 1.0803 \\
\hline$t_{\text {Entry }}$ & 0.0014 & 0.0985 & 0.0006 & 0.0237 \\
\hline D_99 & -0.0185 & -0.6377 & & \\
\hline $\mathrm{R}^{2}$ & 0.07 & & 0.05 & \\
\hline Joint significance: & $F(5,64)=$ & 1.02 & $F(4,36)=$ & 0.49 \\
\hline
\end{tabular}

The results are on Tables 4.3 and 4.4. Note that a decrease of total market's concentration may be due to a decrease of the leader's share (and consequently to an increase of the followers' share), captured mostly by the first HHI, or to a fiercer competition (reduction of inequality, or entry of new competitors) within the similar drugs' segment, which is better captured by the second HHI. Hence, the positive sign of variable HHI_Q combined with the negative sign of HHIG_Q indicates that the two types of market structure movements have different effects on relative price: in the first case, when the market concentration is diminished because of a fall of the leader's share, this means that the similar drugs are gaining room in the market, so they have more market power to raise their prices relative to the leader; in the second case, when the redistribution is within the segment of similar drugs, they compete more intensely among themselves and have their average price reduced as compared to the leader. ${ }^{21}$

21 The estimated mean error in 1999 is zero in the first regression (7 p.p. standard deviation) and 2 percentage points (4 p.p. standard deviation) in the second. 
TABLE 4.4 - RANDOM EFFECTS LEAST SQUARES ESTIMATION

\begin{tabular}{|c|c|c|c|c|}
\hline \multirow[b]{2}{*}{$\mathrm{D} \_\operatorname{Ln}\left(\mathrm{P}^{\mathrm{s}} / \mathrm{P}^{\llcorner}\right)$- Average } & \multicolumn{2}{|c|}{ 1995-99 Sample } & \multicolumn{2}{|c|}{ 1995-98 Sample } \\
\hline & Coefficient & t-Statistic & Coefficient & t-Statistic \\
\hline Constant & -0.0058 & -0.2663 & -0.0058 & -0.2153 \\
\hline$\left(H H I \_Q\right)_{t-1}$ & -0.1028 & $-3.8231^{* * *}$ & -0.1106 & $-3.1949^{* * *}$ \\
\hline$\left(H H I G \_Q\right)_{t-1}$ & 0.0848 & $3.4576^{\star * *}$ & 0.0887 & $2.9501^{* * *}$ \\
\hline$t_{\text {Entry }}$ & 0.0035 & $3.9646^{* * *}$ & 0.0037 & $3.2416^{* * *}$ \\
\hline D_99 & -0.0359 & $-1.8419^{*}$ & & \\
\hline $\mathrm{R}^{2}$ & 0.14 & & $0.10^{-}$ & \\
\hline Joint significance: & $F(10,173)$ & $-5.81^{* * *}$ & $F(8,116)=$ & $3.32^{* * *}$ \\
\hline Hausman test: & $\mathrm{H}=1.5 \overline{\overline{4}}$ & $\begin{array}{c}\operatorname{Prob}\left(\mathrm{H}>\chi^{2}\right. \\
(4))=0.82\end{array}$ & $\mathrm{H}=0.31$ & $\begin{array}{r}\operatorname{Prob}\left(\mathrm{H}>\chi^{2}\right. \\
(3))=0.96\end{array}$ \\
\hline
\end{tabular}

$\left(^{*}\right)$ Significant at 10 percent; $\left({ }^{* *}\right)$ Significant at 5 percent; $\left(^{* *}\right)$ Significant at 1 percent.

The results also indicate that, when the pioneer brands have been facing competition from similar drugs for a longer time, the prices of the latter increase relatively to the former. This means that the ability of similar drugs to raise prices relatively to the leading brand is greater, the greater is the market concentration and the time the consumer had to grow accustomed to having options besides the pioneer brand on the pharmacy's shelf, or, seen from another perspective, it means that the ability of the leading brand to distantiate its price from the similar drugs' is deteriorating.

Combining all these results, we conclude that in markets where the leader's presence is weaker (as measured by market share), the similar drugs are able to raise their prices more easily; on the other hand, a fiercer competition among similar drugs brings their prices down relatively to the leader's. The leader in turn, when it has a more undermined market share, prefers catering to a more price-inelastic segment and raising prices. In sum, we find that the general price level goes up when the followers gain market share: not only does the leader raise its price along time but also the followers are able to raise their prices (on average) relative to the leader, thus reflecting the latter's higher market power. 


\section{CONCLUSIONS}

The results of the regressions indicate that prices of leading drugs respond positively to the wage growth rate in the industry. Price raises are also greater when the leader is losing market share to similar or generic substitutes; this indicates that, very similarly to what Frank and Salkever (1995) found in the U.S., the leaders prefer retreating to a less price elastic market segment, the one that is more reluctant to substitute a similar drug for the pioneer brand. The similar drugs' manufacturers in turn reduce the ratios of their prices to the leaders' in response to the entry of new competitors (on average), but raise them when they win market share over the leaders.

Note that we could not include the exchange rate as an explaining variable, because of an immense multicollinearity with the dummy D_99. If it were included instead, it would come out with the same negative sign of the dummy. The negative impact of the dollar's appreciation against the Real in 1999 on the drug price variation may be surprising. This result, however, just indicates that the domestic currency devaluation is not passed through completely to the local drug prices in real terms. Note that some pass-through indeed occurred: in our sample the raise was 29.45 percent in nominal terms on average. But it was an incomplete pass-through: the exchange rate rose (average against average) 51.83 percent, so the real (PPP) price fell 22.4 percent. Our model fits quite well these figures: in nominal terms, our model predicts a 29.39 percent- raise; in real terms, the PPP figures went down 22.38 percent. ${ }^{22}$

Another important result is that corroborating the product life cycle theory, the power to raise prices of the laboratories is increasing up to a certain point (approximately twenty eight years, the turning point of our estimated polynomial) and then eroding. Note that our estimates point out to a very long life cycle, with a turning point above, for instance, the patent life in the U.S. This agrees with the theory described in the previous sections.

The results obtained contradict the usual intuition that entry of new competitors should lead to a reduction of prices charged by leading firms. Our estimates point out exactly to the opposite: in consonance with empirical

22 All the variations are calculated on the yearly averages. 
studies undertaken in developed countries, we estimated that leading drug prices react positively to penetration of similar drugs into the market; the flip side of the coin is that the average level of similar or generic drug prices tends to go down and its dispersion relatively to the leader's price tends to go up when competition within the fringe becomes tougher. If on the other hand the fringe (especially if there is some sort of "sub-leader" included as a follower) wins a greater market share, the prices of similar drugs tend to go up relatively to the leader.

This result signals that measures facilitating generic drugs' entry will have differentiated effects on the consumer, according to the segments they belong to: more conservative consumers, who refuse to substitute a generic/similar drug for the leading brand, will face a rise of their medical care costs, while those more willing to accept a replacement will in average face lower and lower prices as the market is pulverized among various suppliers. This means that the dissemination of generic drugs will have progressive effects on income distribution if the consumers' degree of conservativeness is positively correlated to their income.

The finding that the prices of similar drugs increase relatively to the leader, the longer they have been in the market, suggests that the beneficial impact of entry is diluted as time goes by.

The estimated model also demonstrates that macroeconomic cost (wage) shocks influence positively the industry's inflation; on the other hand, demand shocks (variations of domestic income, interest rate and general inflation) could not be identified, because they were too correlated to labor costs and the exchange rate shock of 1999 . The combination of these shocks with the subsequent government intervention, negotiating an agreement with the industry representatives, are responsible for the price increase being 21 percentage points below what PPP would project to 1999, given the direct shock in the exchange rate.

It will be interesting to check in the future the effects of the new Generic Drugs Act and of the massive advertising campaign ran by the Ministry of Health thereafter on the consumer's perception regarding substitutability among branded, generic and branded generic ("similar", which did not undergo bioavailability tests) drugs. It is quite possible that this massive campaign in the media reduces dispersion of consumers' information and 
consequently the price dispersion as well, even if market concentration goes up. Thus, in case a reduction of informational asymmetry about generic drugs' quality occurs, it is possible that a reduction of market concentration leads to a decrease of the leading drugs' prices.

Another interesting exercise will be assessing the entry of generic drugs in markets currently protected by patent when the first patents expire, as a comparison to the retrospect of developed countries will be much more immediate.

\section{REFERENCES}

ANDRADE, M.; LISBOA, M. Regulação do setor saúde no Brasil. Rio de Janeiro: EPGE/FGV, 2001. Mimeografado.

BALTAGI, Badi H. Simultaneous equations with error components. Journal of Econometrics, n. 17, p. 189-200, 1981.

BERNDT, Ernst; PINDYCK, Robert; AZOULAY, Pierre. Consumption externalities and diffusion in pharmacentical markets: antiulcer drugs. Cambridge, Mass.: NBER, 2000. (Working Paper; 7772).

CAVES, Richard E.; WHINSTON, Michael D.; HURWITZ, Mark A. Patent expiration, entry and competition in the U.S. pharmaceutical industry. Brookings Papers on Economic Activity, 1991. Special issue.

DARBY, Michael; KARNI, Edi. Free Competition and the Optimal Amount of Fraud. Journal of Law and Economics, n. 16, p. 67-88, 1973.

DI MASI, A. et al. Cost of innovation in the pharmaceutical industry. Journal of Health Economics, v. 10, n. 2, p. 107-142, 1991.

FAGAN, Perry L. As gigantes farmacêuticas: prontas para o século XXI?. Cambridge, Mass.: Harvard Business School, 1998. Note 9-698070 .

FRANK, Richard; SALKEVER, David. Pricing, patent loss and the market for pharmaceuticals. Cambridge, Mass.: NBER, 1991. (Working Paper; 3803).

. Generic entry and the pricing of pharmaceuticals. Cambridge, Mass.: NBER, 1995. (Working Paper; 5306).

GRABOWSKI, Henry G.; VERNON, John M. Brand loyalty, entry, and price competition in pharmaceuticals after the 1984 Drug Act. Journal of Law and Economics, v. 35, n. 2, p. 331-350, 1992. 
HAUSMAN, J. A. Specification tests in econometrics. Econometrica, v. 46, n. 6, p. 1251-71, 1978.

HELLERSTEIN, Judith. The demand for post-patent prescription pharmaceuticals. Cambridge, Mass.: NBER, 1994. (Working Paper; 4981).

HURWITZ, Mark; CAVES, Richard. Persuasion or information? Promotion and the shares of brand name and generic pharmaceuticals. Journal of Law \& Economics, v. 31, n. 2, p. 299-320, 1988.

LEFFLER, Keith. Persuasion or information? The economics of prescription drug advertising. Journal of Law and Economics, v. 24, n. 1, p. 5-74, 1981.

LEVIN, Richard; KLEVORICK, Alvin; NELSON, Richard; WINTER, Sidney. Appropriating the returns from industrial research and development. Brookings Papers on Economic Activity, v. 3, n. 0, p. 783-820, 1987.

LICHTENBERG, Frank R. Do (more and better) drugs keep people out of hospitals? American Economic Review, v. 86, n. 2, p. 384-388, 1996a.

. The effect of pharmaceutical utilization and innovation on hospitalization and mortality. Cambridge, Mass.: NBER, 1996b. (Working Paper; 5418).

- Pharmaceutical innovation, mortality reduction and economic growth. Cambridge, Mass.: NBER, 1998. (Working Paper; 6569).

. The benefits and costs of new drugs: evidence from the 1996 Medical Expenditure Panel Survey. Cambridge, Mass.: NBER, 2001. (Working Paper; 8147).

LISBOA, Marcos B.;MOREIRA, Humberto. On capitation contracts and endogenous altruism: the managed care. Rio de Janeiro, 2000. Mimeografado.

LOYOLA, Maria Andréa. Médicos e curandeiros: conflito social e saúde. São Paulo: DIFEL, 1984.

MANSFIELD, Edwin. Patents and innovation: an empirical study. Management Science, v. 32, n. 2, p. 173-181, 1986.

NELSON, Phillip. Information and consumer behavior. Journal of Political Economy, n. 78, p. 311-329, 1970.

NOGUÉS, Júlio. Patents and pharmaceutical drugs: understanding the pressures on developing countries. Washington (D.C.): World Bank, 1990. (International Economics Department Working Paper Series; 502).

PELTZMAN, Sam. An evaluation of consumer protection legislation: the 1962 drug amendments. Journal of Political Economy, v. 81, n. 5, p. 1049-91, 1973. 
PEPE, Vera L. E.; VERAS, Cláudia M. T. A prescrição médica. Instituto de Medicina Social - UERJ, 1995. (Série Estudos em Saúde Coletiva, 111).

Phrma - Pharmaceutical Researchers' and Manufacturers' AssociaTION. Pharmaceutical industry profile 2000, 2000. Downloadable from: http://www.phrma.org

QUEIROZ, Sérgio; GONZÁLEZ, Alexis. Mudanças recentes na estrutura produtiva da indústria farmacêutica. In: NEGRI, Barjas; Di GIOvanNI, Geraldo (eds.), Brasil: radiografia da saúde. Campinas, SP: IE-UNICAMP, 2001.

RÊGO, Elba C.L. Políticas de regulação do mercado de medicamentos: a experiência internacional. Revista do BNDES, v. 7, n. 14, p. 367-400, 2000 .

RUPPRECHT, Fréderic.Le marché du médicament: évolutions depuis 1980. In: MOUGEOT, M. (org.), Régulation du systeme de santé. Paris: La Documentation Française, 1999.

SAKAKIBARA, Mariko; BRANSTETTER, Lee. Do stronger patents induce more innovation? Evidence from the 1988 Japanese patent law reforms. Rand Journal of Economics, v. 32, n. 1, p. 77-100, 2001.

SILVA, Ricardo I. Indústria farmacêutica brasileira: estrutura e a questão dos preços de transferência. 1999. Unpublished Doctoral Dissertation - Escola de Quimica. UFRJ.

TEMIN, Peter. Taking your medicine: drug regulation in the United States. Cambridge, Mass.: Harvard University Press, 1980.

TIROLE, Jean. The theory of industrial organization. Cambridge, Mass.: MIT Press, 1988.

VISCUSI, W. Kip; VERNON, John; HARRINGTON, JR., Joseph E. Economic of regulation and antitrust. $2^{\text {nd }} \mathrm{ed}$. Cambrige, Mass.: MIT Press, 1995.

\footnotetext{
This research has been sponsored by the Brazilian Fund for the Defense of Diffuse Rights. We gratefully acknowledge Paulo Correa, Cláudia Vidal, Cristiane Schmidt, Kélvia Frota and Sidney Rodrigues, from the Brazilian Ministry of Finance, for valuable cooperation; César Dalston, from the Federal Revenue Secretariat, for his kind and prompt help on classifying drugs in our sample according to official tariff categories; Marcos de Barros, from Fundação Getúlio Vargas, for his excellent work on organizing the data bank; and to Ingreed Valdez, Ana Paula Razal and Adrian Herringer, from IPEA, for their assistance on data manipulation. We are also grateful to Afonso Arinos Neto, Eduardo Pontual Ribeiro, Naércio Menezes-Filho and participants of seminars at PUC-RJ, EPGE, SEAE/MF, and IPEA, and LAMES and LACEA meetings, and to two anonymous referees of this journal for valuable comments and suggestions The usual caveat applies.
}

(Recebido em junho de 2002. Aceito para publicação em julho de 2003.) 